\title{
Molecular determinants of Smac mimetic induced degradation of CIAP1 and cIAP2
}

\author{
M Darding ${ }^{1}$, R Feltham ${ }^{2,4}$, T Tenev $^{1,4}$, K Bianchi $^{1}$, C Benetatos ${ }^{3}$, J Silke ${ }^{2}$ and P Meier ${ }^{*, 1}$
}

The inhibitors of apoptosis (IAP) proteins CIAP1 and cIAP2 have recently emerged as key ubiquitin-E3 ligases regulating innate immunity and cell survival. Much of our knowledge of these IAPs stems from studies using pharmacological inhibitors of IAPs, dubbed Smac mimetics (SMs). Although SMs stimulate auto-ubiquitylation and degradation of cIAPs, little is known about the molecular determinants through which SMs activate the E3 activities of cIAPs. In this study, we find that SM-induced rapid degradation of cIAPs requires binding to tumour necrosis factor (TNF) receptor-associated factor 2 (TRAF2). Moreover, our data reveal an unexpected difference between cIAP1 and cIAP2. Although SM-induced degradation of cIAP1 does not require cIAP2, degradation of cIAP2 critically depends on the presence of cIAP1. In addition, degradation of cIAP2 also requires the ability of the cIAP2 RING finger to dimerise and to bind to E2s. This has important implications because SM-mediated degradation of cIAP1 causes non-canonical activation of NF- $\kappa \mathrm{B}$, which results in the induction of clAP2 gene expression. In the absence of cIAP1, de novo synthesised CIAP2 is resistant to the SM and suppresses TNF $\alpha$ killing. Furthermore, the cIAP2-MALT1 oncogene, which lacks cIAP2's RING, is resistant to SM treatment. The identification of mechanisms through which cancer cells resist SM treatment will help to improve combination therapies aimed at enhancing treatment response.

Cell Death and Differentiation (2011) 18, 1376-1386; doi:10.1038/cdd.2011.10; published online 18 February 2011

Advances in our understanding of the molecular mechanisms through which cancer cells bypass the apoptotic programme has aided the design of novel, potentially more selective and effective strategies for cancer treatment. The development of Smac mimetic (SM) compounds, designed to inhibit members of the inhibitor of apoptosis protein (IAP) family and to sensitise cancer cells to death, represents such an approach. ${ }^{1}$

SM compounds are a class of small pharmacological molecules that mimic the amino-terminal IAP-binding motif (AVPI) of mature Smac (also known as DIABLO), a member of the loosely defined family of IAP antagonists. ${ }^{2}$ These compounds selectively bind to the Baculoviral IAP Repeat (BIR)2 and BIR3 domains of numerous IAPs. ${ }^{3}$ The mammalian IAPs, XIAP, cIAP1 and cIAP2 contain three such domains in their amino-terminal portion. These IAPs also harbour additional domains such as the RING-finger domain that provides them with Ubiquitin (Ub) ligase (E3) activity, ${ }^{4}$ a Ub-associated domain through which they interact with ubiquitylated proteins, ${ }^{5,6}$ and in the situation of CIAP1 and clAP2, a caspase-recruitment domain of unknown function.

Although IAPs are best known for their ability to inhibit caspases, ${ }^{7}$ they also fulfil survival-signalling functions independent of controlling caspases. In particular, cIAP1 and clAP2 modulate Ub-dependent signalling events that regulate $\mathrm{NF}-\kappa \mathrm{B}$. clAPs are required for stimulus-dependent activation of the canonical pathway and for constitutive suppression of the non-canonical NF- $\kappa$ B pathway. ${ }^{8-15}$

Under unstimulated conditions, non-canonical NF- $\kappa \mathrm{B}$ signalling is suppressed by clAP-mediated degradation of $N F-\kappa B$-inducing kinase (NIK). clAP-mediated degradation of NIK also requires tumour necrosis factor (TNF) receptorassociated factor (TRAF)2 and TRAF3, which function as adaptor proteins recruiting NIK to clAPs. Loss of TRAF2, TRAF3 or clAPs prevents NIK turnover and results in the accumulation of NIK protein levels and in the stimulation of non-canonical NF- $\kappa \mathrm{B}$ signalling. ${ }^{8}$ In the situation of the canonical NF- $\kappa$ B pathway, stimulation with TNF $\alpha$ leads to recruitment of clAPs through TRAF2 to the plasma membrane-bound TNF receptor 1 (TNF-R1) signalling complex, dubbed complex-I. After its recruitment, clAPs promote ubiquitylation of components of this complex, such as receptor-interacting protein 1 (RIP1). ${ }^{16}$ This in turn stimulates the recruitment of the kinase complexes TAK1-TAB2-TAB3 and NEMO-IKK $\alpha-\mathrm{IKK} \beta$ and ultimately results in the nuclear translocation of NF- $\kappa$ B dimers. Recent studies have indicated that clAPs are not only required for proper regulation of $N F-\kappa B$ but also for suppression of cell death during TNF $\alpha$ signalling. ${ }^{9,11,12,14,17,18}$

Although originally designed to inactivate XIAP, SMs are most effective with clAP1 and clAP2. Within minutes of

${ }^{1}$ Chester Beatty Laboratories, The Breakthrough Toby Robins Breast Cancer Research Centre, Institute of Cancer Research, Mary-Jean Mitchell Green Building, Fulham Road, London SW3 6JB, UK; ${ }^{2}$ Department of Biochemistry, Level 4 RL Reid Building, La Trobe University, Victoria 3086, Australia and ${ }^{3}$ TetraLogic Pharmaceuticals, 343 Phoenixville Pike, Malvern, PA 19355, USA

${ }^{*}$ Corresponding author: P Meier, Chester Beatty Laboratories, The Breakthrough Toby Robins Breast Cancer Research Centre, Institute of Cancer Research, Mary-Jean Mitchell Green Building, Fulham Road, London SW3 6JB, UK. Tel: + 440207153 5326; Fax: + 440207153 5340; E-mail: pmeier@icr.ac.uk

${ }^{4}$ These authors contributed equally to this work.

Keywords: cIAP1; clAP2; Smac mimetic; TNF $\alpha$; TRAF2; ubiquitin

Abbreviations: SM, Smac mimetic; IAP, inhibitor of apoptosis protein; BIR, Baculoviral IAP repeat; RING, Really Interesting New Gene; TNF $\alpha$, tumour necrosis factor- $\alpha$; NIK, NF- $\kappa$ B inducing kinase; TRAF, TNF receptor-associated factor; RIP1, receptor-interacting protein 1; MALT, mucosa-associated lymphoid tissue; MEF, mouse embryonic fibroblast; DKO, double knockout; Ub, ubiquitin

Received 01.10.10; revised 05.1.11; accepted 07.1.11; Edited by C Duckett; published online 18.2.11 
exposure, SMs trigger auto-ubiquitylation and proteasomal degradation of CIAP1 and CIAP2-although clAP2 is depleted with slower kinetics in most cases. ${ }^{9,11,12,14,17,19}$ This results in stabilisation of NIK and spontaneous activation of non-canonical NF- $\kappa \mathrm{B}$. In SM-sensitive cells, this leads to $\mathrm{NF}-\kappa \mathrm{B}-$ mediated production of autocrine $\mathrm{TNF} \alpha$, overstimulation of TNF-R1, followed by RIP1-dependent cell death.

Over the last few years, several small pharmacological inhibitors of these IAPs have been developed that are currently undergoing clinical trails. Although it is clear that these compounds stimulate auto-ubiquitylation and degradation of clAPs, it remains enigmatic how such SMs promote activation of the E3 ligase activity of these clAPs. In this study, we show that TRAF2 is required for SM-induced degradation of clAP1 and clAP2. Moreover, our data reveal an unexpected difference between clAP1 and clAP2 in their response to SM treatment.

\section{Results}

TRAF2 is required for SM-induced degradation of cIAP1. Despite the importance of TRAF2 for clAP function, ${ }^{20}$ little is currently known regarding the contribution of TRAF2 to SM-induced rapid degradation of clAPs. Using biotinylated SMs that bind clAP1 and clAP2, ${ }^{17}$ we found that TRAF2 readily co-purified with clAP1 and clAP2, indicating that SM-bound clAPs are associated with TRAF2 (Figure 1a). To examine the requirement of TRAF2 for SM-induced degradation of clAP1, we tested three different SMs: the bivalent compound $\mathrm{A}$ (Comp. A ${ }^{11}$ and the monovalent SMs Comp. C (RF and JS, unpublished observation) and LBW242. ${ }^{14}$ Although all three SMs triggered depletion of endogenous clAP1 in WT mouse embryonic fibroblasts (MEFs) (Figure $1 b$ ), TRAF2 ${ }^{-1-}$ MEFs were refractory to rapid SM-induced degradation of clAP1. To exclude the possibility that this effect was due to a genetic drift among different cell lines, rather than due to the specific loss of TRAF2, we used MEFs with loxP sites on either side of the TRAF2 gene (MEF ${ }^{\text {loxP-T2-loxP }}$ (Figure 1c). After infection with a lentivirusexpressing Cre recombinase, TRAF2 is removed resulting in conditionally knocked out TRAF2 ${ }^{\text {cko-l- }}$ MEFs that are otherwise genetically identical to the parental MEF ${ }^{\text {loxP-T2-loxP }}$. When treated with LBW242, TRAF2 ${ }^{\text {cko-l- }}$ MEFs were resistant to SM-induced degradation of clAP1. Under the same conditions, SMs did induce clAP1 degradation in control MEF ${ }^{\text {loxP-T2-loxP }}$ that expressed GFP instead of Cre recombinase (Figure 1c). Taken together, these results demonstrate that SMs are most effective at degrading clAP1 when TRAF2 is present.

Next, we tested the requirement of TRAF1 and TRAF3 for SM-induced degradation of clAP1. TRAF1 can bind ClAP1 directly, whereas TRAF3 binds clAPs indirectly through TRAF2. ${ }^{8,21-23}$ Unlike TRAF2, the loss of TRAF1 or TRAF3 did not block SM-induced degradation of clAP1 (Figure 1d), although the loss of TRAF3 slightly delayed SM-stimulated clAP1 depletion (Figure 1d). Importantly, the inability of the SM to induce clAP1 degradation in TRAF2 ${ }^{-1-}$ MEFs was not due to a failure of clAP1 to bind to the SM in the absence of TRAF2 (Figure 1e). Taken together, these results indicate that
TRAF2, but not TRAF1 or TRAF3, is required for SM-induced clAP1 degradation.

The loss of TRAF2 causes constitutive activation of the non-canonical NF- $\kappa$ B pathway. ${ }^{11,24,25}$ As NF- $\kappa$ B transcription factors induce expression of a large number of target genes the products of which might influence SM-mediated degradation of clAP1, we generated TRAF2 ${ }^{-1-}$ MEFs in which NF- $\kappa$ Bmediated induction of target genes was blocked by expressing $\mathrm{I}_{\kappa} \mathrm{B}$-super repressor ( $\left.\mathrm{k}_{\kappa} \mathrm{B}-\mathrm{SR}\right)$, a non-degradable, dominant negative form of the NF- $\kappa \mathrm{B}$ inhibitor, $\mathrm{I} \kappa \mathrm{B}$ (Figure $1 \mathrm{f}$ and Supplementary Figure S1). It is noteworthy that $I_{\kappa} \mathrm{B}-\mathrm{SR}$ blocks gene induction in response to canonical and non-canonical NF- $\kappa$ B-signalling (Supplementary Figure S1 and Vince et $\left.a .^{11}\right)$. Although $I_{\kappa} \mathrm{B}-\mathrm{SR}$ blocked NF- $\kappa \mathrm{B}-$ mediated gene expression, it failed to restore SM-induced cIAP1 degradation in TRAF2 ${ }^{-1-}$ MEFs (Figure $1 \mathrm{~g}$ ). Moreover, knockdown of NIK or p100 did not influence SM-induced degradation of clAP1 in TRAF2-deficient cells (Supplementary Figure S1). This indicates that the inability of the SM to trigger clAP1 degradation in TRAF2 $^{-1-}$ MEFs is not caused by NIK or upregulation of some putative NF- $\kappa \mathrm{B}$ target gene products, but instead is due to the specific loss of TRAF2.

SM-induced degradation of cIAP1 requires TRAF2 binding but not TRAF2's E3 ligase activity. Given that clAP1 binds to TRAF2 through BIR1, ${ }^{21,22}$ we examined the role of the BIR1 domain for SM-induced degradation of clAP1. To this end, we transiently transfected HEK293T cells with ClAP ${ }^{\mathrm{WT}}$ and $\mathrm{ClAP} 1^{\triangle \mathrm{BIR} 1}$ that lacks the BIR1 domain and therefore fails to bind to TRAF2 (Figure $2 a$ and Supplementary Figure S2). SM-induced degradation of clAP1 was dependent on TRAF2 binding because treatment with LBW242 failed to efficiently deplete $\mathrm{clAP}^{\Delta \mathrm{BIR} 1}$ while ClAP1 ${ }^{\mathrm{WT}}$ was rapidly degraded (Figure $2 \mathrm{~b}$ ). It is noteworthy that $\operatorname{ClAP}^{\triangle \mathrm{BIR} 1}$ is partially degraded by the SM compound under these conditions, although to a lesser extent than wildtype clAP1. Most likely, this is due to the overexpression conditions using HEK293T cells. SM-induced clAP1 degradation was not rescued in TRAF2 ${ }^{-1-}$ MEFs reconstituted with TRAF2 ${ }^{\triangle \mathrm{CIM}}$, a TRAF2 mutant that lacks the clAP1interacting motive (CIM, $\Delta 283-293)^{20}$ (Figure 2c). In contrast, reconstitution of TRAF2 ${ }^{-1-}$ MEFs with TRAF2 ${ }^{\text {WT }}$ or TRAF2 ${ }^{\triangle R I N G}$, which lacks its amino-terminal RING-finger domain, rescued SM-induced degradation of clAP1. Together with previous data, these results indicate that apart from a functional RING of CIAP1 and binding of the SM to the BIR2/3 domains, binding of TRAF2 to clAP1 is necessary for SM-induced clAP1 degradation. Although TRAF2 carries a RING finger, this domain is dispensable for SM-induced degradation of CIAP1, ruling out the possibility that TRAF2 acts as the E3 for cIAP1.

Next, we addressed whether TRAF2 contributes to SMinduced degradation by enhancing the E3 ligase activity of clAP1. Recombinant clAP1 possesses intrinsic E3 ligase activity even in the absence of TRAF2 under in vitro conditions. ${ }^{9,12}$ Accordingly, clAP1 promotes auto-ubiquitylation in an in vitro assay in a concentration-dependent manner (Figure 2d). When increasing amounts of TRAF2 were added to the reaction, TRAF2 did not change cIAP1-mediated autoubiquitylation (Figure 2e), indicating that TRAF2 does not 
a

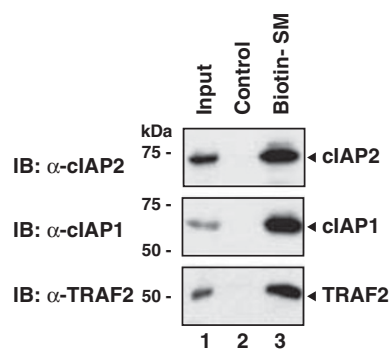

C

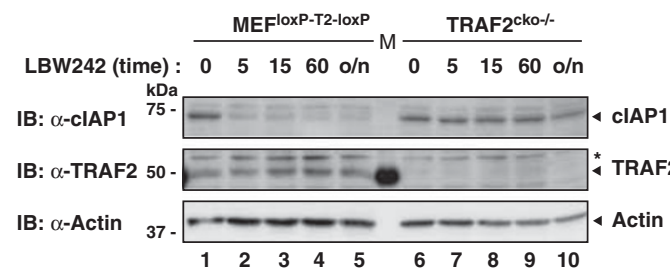

b

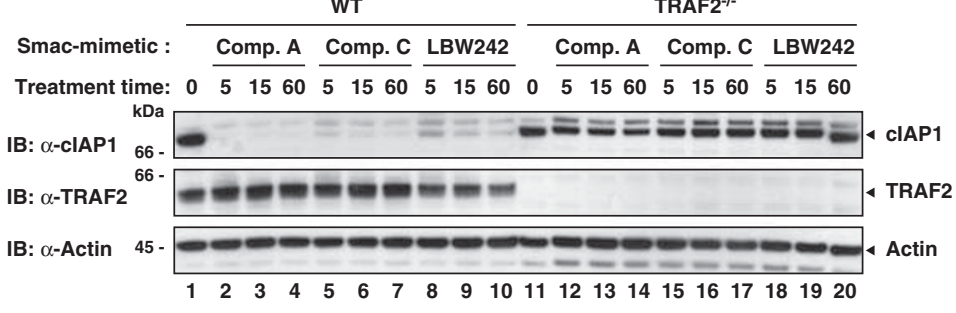

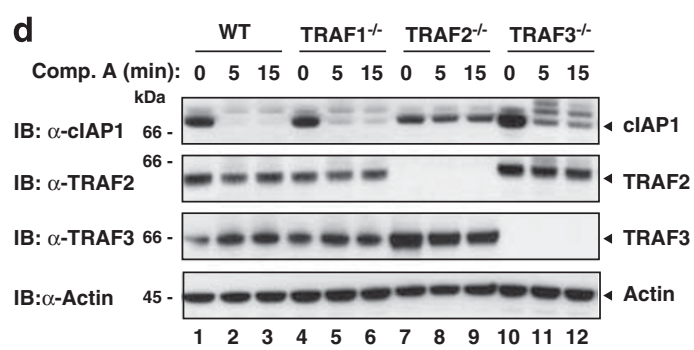

d e

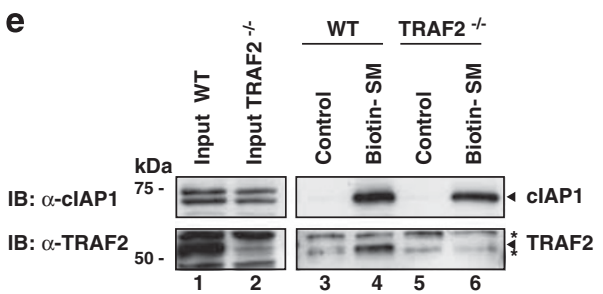

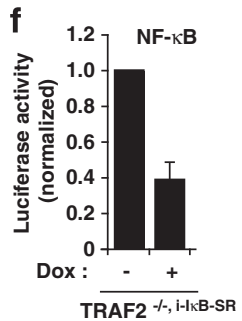

g

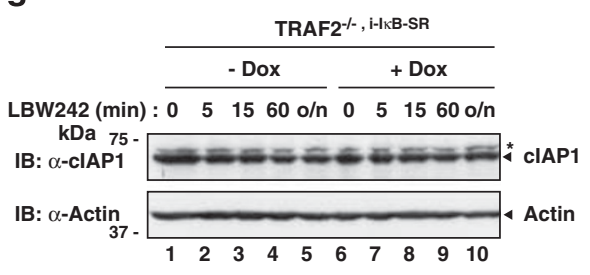

Figure 1 TRAF2 is required for Smac mimetic (SM)-induced cIAP1 degradation. (a and e) Biotinylated SM was used to purify SM-binding proteins from lysates of MDAMB-231 (a) and MEFs (e). The presence of co-purified proteins was established by immunoblotting the eluate with the indicated antibodies. (b-d and $\mathbf{g}$ ) WT and TRAF-knockout MEFs were treated with $100 \mathrm{nM}$ Comp. A, $100 \mathrm{nM}$ Comp. C and $1 \mu \mathrm{M}$ LBW242 for the indicated time points (min). The presence of the indicated proteins was established by immunoblotting the lysates with the indicated antibodies. Asterisks indicate nonspecific bands. (f) Secreted luciferase reporter assays using TRAF2 $2^{-l-, i-\mid \kappa B-S R}$ MEFs. Cells were left untreated or treated with $100 \mathrm{ng} / \mathrm{ml}$ doxocycline (Dox) to induce $1 \kappa \mathrm{B}-\mathrm{SR}$. The medium was analysed for luciferase activity $24 \mathrm{~h}$ later. Luciferase activity is shown relative to the uninduced condition. The error bar indicates S.D. of triplicate experiments. (g) TRAF2 ${ }^{-l-, i-l \kappa B-S R}$ MEFs were left uninduced or induced with Dox and treated with $1 \mu \mathrm{M}$ LBW242 for the indicated time points

enhance the intrinsic E3 ligase activity of clAP1 under these conditions.

To address the possibility that TRAF2 recruits ubiquitylated cIAP1 to the degradation machinery, we examined whether auto-ubiquitylated clAP1 accumulates in the absence of TRAF2. In the absence of TRAF2, we failed to detect any discernable levels of ubiquitylated clAP1 (Figure 2f), rendering it unlikely that TRAF2 recruits ubiquitylated cIAPs to the proteasome. Taken together, our data are consistent with a model in which TRAF2 functions as an essential cofactor for clAP1's E3 activity upon SM treatment because it acts as a scaffold allowing high local concentration of clAP1. This might facilitate dimerisation of clAP's RING, which is required for clAPs' E3 activity. ${ }^{26,27}$ According to this scenario, clAP1 RING dimerisation may be hampered in the absence of TRAF2.

SM-induced degradation of clAP2 is dependent on TRAF2 and cIAP1. Next, we tested whether TRAF2 is also required for SM-mediated degradation of clAP2. As there are currently no good antibodies available that would detect mouse cIAP2 at endogenous levels, we generated $\mathrm{WT}^{\mathrm{i}-\mathrm{CIAP} 2}$ and TRAF2 ${ }^{-1-; \mathrm{i}-\mathrm{ClAP} 2}$ MEFs that carry an inducible transgene encoding human clAP2, for which good antibodies exist. Like for clAP1, clAP2 was readily degraded in WT MEFs (Figure 3a). However, MEFs lacking TRAF2 showed impaired degradation of clAP2. Interestingly, when clAP2 was introduced into clAP1/2 double-knockout (DKO) MEFs, LBW242 treatment failed to induce rapid degradation of clAP2 (Figures $3 a$ and $b$ ), indicating that clAP2 degradation critically depends on the presence of clAP1. In contrast, degradation of CIAP1 was not dependent on clAP2, as clAP1 reconstituted in DKO MEFs was efficiently degraded upon LBW242 treatment (Figure 3c). Importantly, clAP1 was not required for clAP2 to bind to the SM compound, nor did it affect clAP2's ability to bind to TRAF2 (Figure 3d). Furthermore, SM-mediated degradation of clAP2 was also impaired in human cells, in which clAP1 was knocked down by RNA interference (RNAi) (Supplementary Figure S3, see the Materials and Methods section for details). These results indicate that clAP2 relies on the E3 activity of clAP1 for its degradation upon SM treatment. This observation is consistent with earlier reports suggesting that clAP1 targets cIAP2 for proteasomal degradation. ${ }^{28,29}$ Although clAP2 fails to promote its own degradation in the absence of clAP1 under these conditions, clAP2 is not generally inactive as E3. In the absence of clAP1, clAP2 readily promoted TNFinduced ubiquitylation of RIP1, degradation of NIK and 


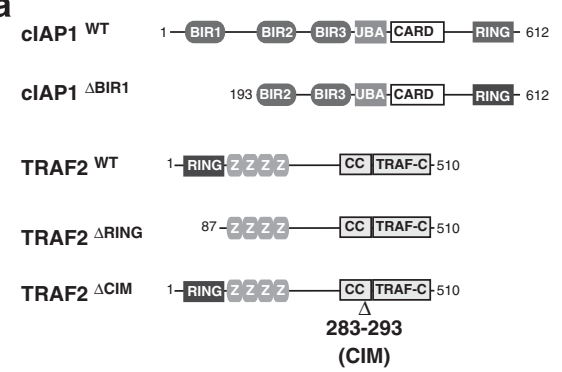

C

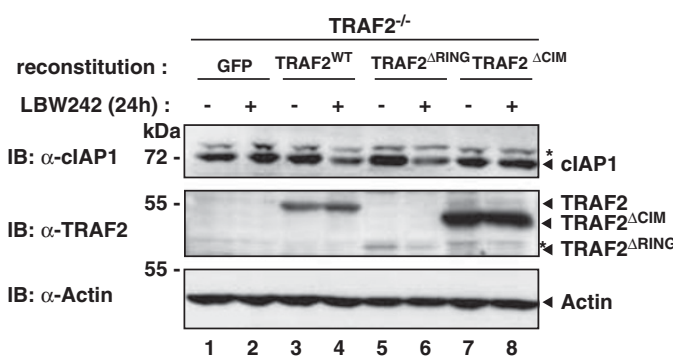

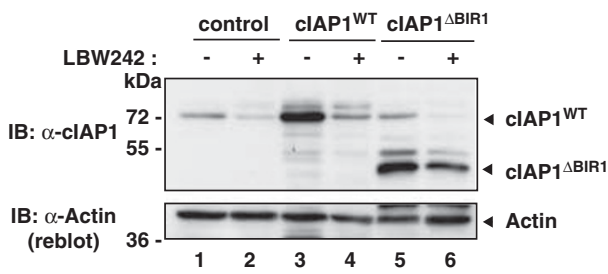

d
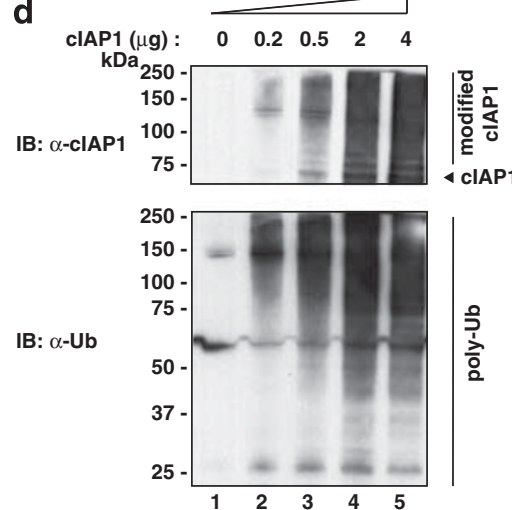

e
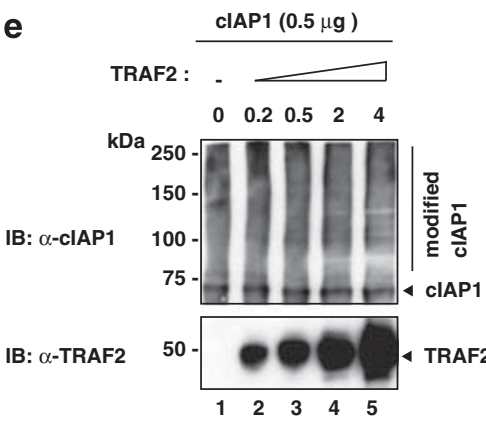

f

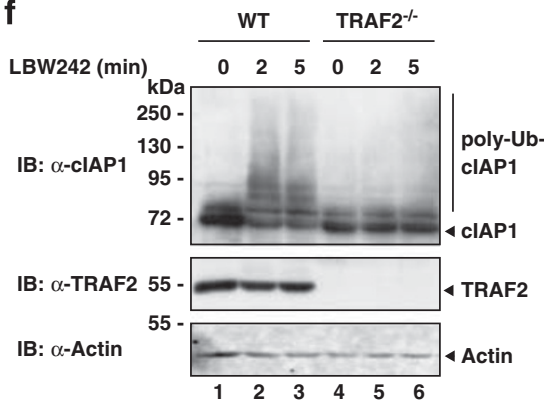

Figure 2 SM-induced cIAP1 degradation requires binding to TRAF2. (a) Schematic representation of the constructs used in $\mathbf{b}$ and $\mathbf{c}$. (b) HEK293T cells were transiently transfected with a control plasmid or plasmids expressing either clAP1 ${ }^{\mathrm{WT}}$ or clAP1 ${ }^{\triangle \mathrm{BIR} 1}$. Cells were left untreated or treated with $1 \mu \mathrm{M}$ LBW242 for 30 min. (c) TRAF2 ${ }^{-1-}$ MEFs were stably infected with plasmids inducibly expressing GFP, TRAF2 ${ }^{\text {WT }}$, TRAF2 ${ }^{\triangle \mathrm{RING}}$ and TRAF2 ${ }^{\Delta \mathrm{CIM}}$, respectively. Expression of the indicated proteins was induced with $2 \mathrm{nM}$ 4-hydroxy-tamoxifen, and cells were left untreated or treated with $1 \mu \mathrm{M}$ LBW242 for $16 \mathrm{~h}$ before analysis. Asterisks indicate nonspecific bands. (d and e) Recombinant cIAP1 was analysed for its E3 ligase activity in vitro. The indicated amounts of CIAP1 and TRAF2 were incubated with a reaction mixture containing Ub, ATP, E1 and E2 (UbcH5c) enzymes. (f) WT and TRAF2 ${ }^{-1-}$ MEFs were treated with $1 \mu \mathrm{M} \mathrm{LBW242}$ for the indicated time points

suppression of 100 processing (Figures $3 \mathrm{e}-\mathrm{g}$ ). Therefore, clAP2 is fully competent in promoting ubiquitylation of bona fide substrates. However, in the absence of clAP1, clAP2's E3 ligase activity does not allow auto-ubiquitylation in response to SM treatment.

RING dimerisation and E2 binding is required for cIAP2 degradation. Next, we addressed the role of clAP2's own RING finger for SM-induced, clAP1-directed degradation of clAP2. To this end, we focussed on clAP2 ${ }^{\triangle \mathrm{RING}}$ lacking the RING finger, the RING-dimerisation mutant CIAP2 $^{\mathrm{V} 568 \mathrm{E}}$ and the E2-binding mutant $\mathrm{ClAP} 2^{\mathrm{L585A} / 1590 \mathrm{~A}}$ (RF and JS, unpublished observation). Although LBW242 readily degraded $\operatorname{clAP} 2^{\mathrm{WT}}$, it was ineffective in degrading clAP2 ${ }^{\triangle \mathrm{RING}}, \operatorname{clAP2}^{\mathrm{V} 568 \mathrm{E}}$ or $\mathrm{ClAP2} 2^{\mathrm{L} 585 \mathrm{~A} / 1590 \mathrm{~A}}$ (Figure $4 \mathrm{a}$ ). This indicates that RING dimerisation and E2 binding of clAP2 is required for SM-induced degradation.
The loss of clAP2's RING finger is frequently found in cIAP2-MALT1. Reciprocal chromosomal translocation of clAP2 and the paracaspase MALT1 gene is the most prevalent chromosomal aberration associated with MALT lymphoma (Figure 4b). ${ }^{30}$ clAP2-MALT1 drives B-cell transformation and lymphoma progression through constitutive activation of the canonical NF- $\kappa$ B signalling pathway. ${ }^{31}$ Induced degradation of the cIAP2-MALT1 protein by SM compounds could potentially provide a therapeutic strategy for MALT lymphoma patients harbouring this translocation. Intriguingly, cIAP2-MALT1 was completely refractory to SM-induced degradation (Figure 4c). In addition, when only the cIAP2 portion of clAP2-MALT1 was expressed (ClAP2 ${ }^{1-442}$ ), SM treatment did not induce degradation, ruling out an inhibitory role of the MALT1 portion of clAP2-MALT1 (Figure 4c). Under the same conditions, full-length cIAP2 was readily degraded (Figure 4a and data not shown). Consistent with the notion that clAP2-MALT1 is 
a

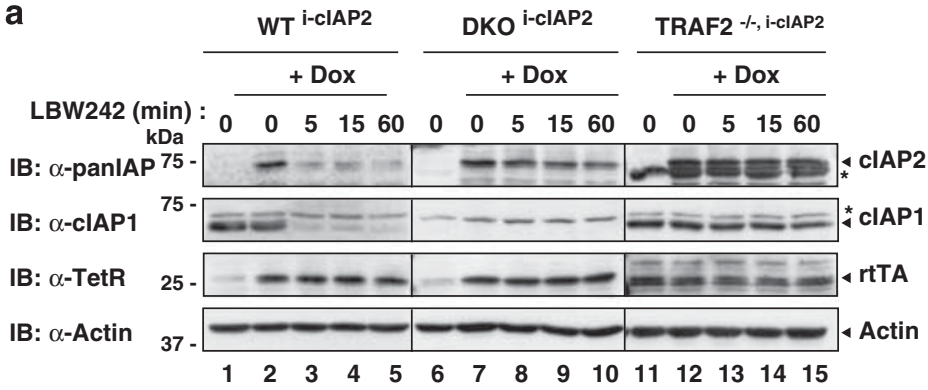

b
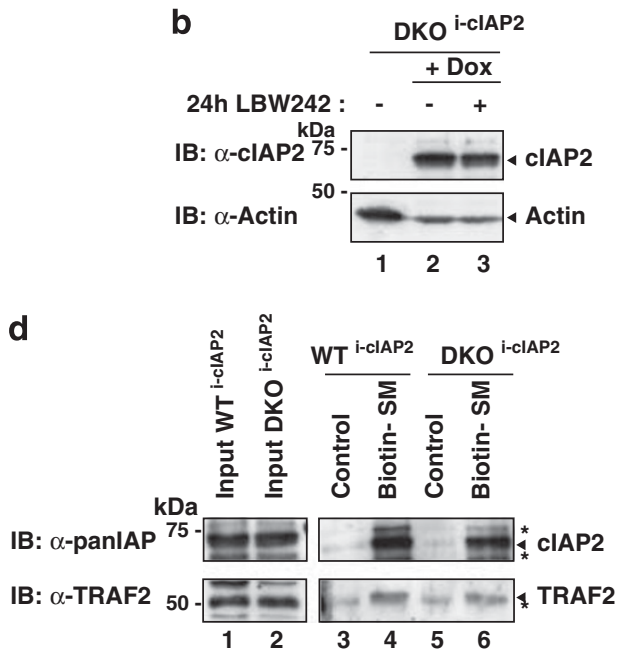

$\mathbf{f}$

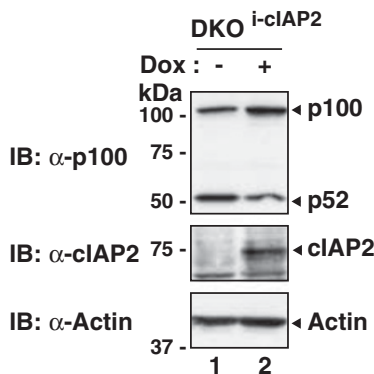

g c

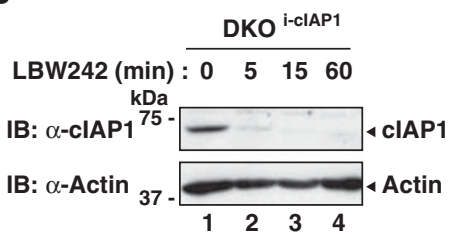

e
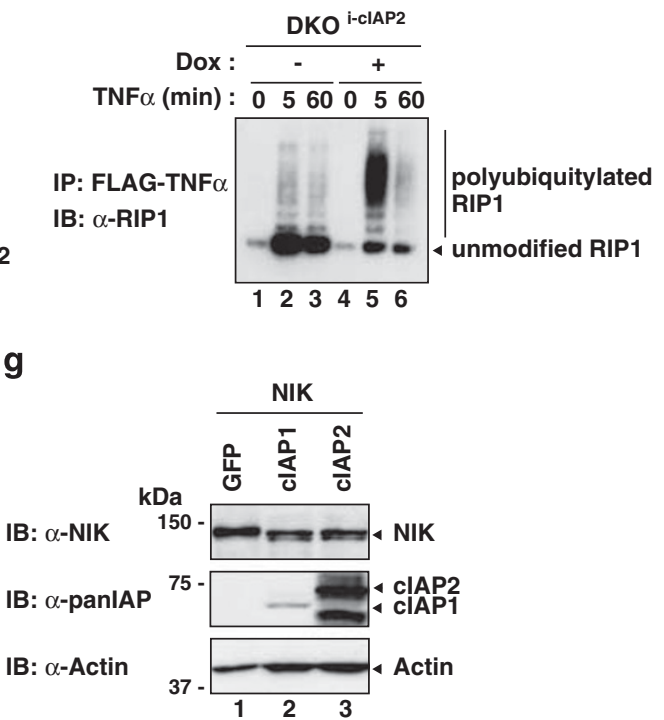

Figure 3 SM-induced degradation of CIAP2 depends on both CIAP1 and TRAF2. (a) WT, TRAF2 ${ }^{-l-}$ and CIAP1/2 double-knockout (DKO) MEFs stably infected with plasmids inducibly expressing cIAP2 (i-clAP2) were treated with Dox for $16 \mathrm{~h}$ and exposed to $1 \mu \mathrm{M} \mathrm{LBW} 242$ for the indicated time points. Asterisks indicate nonspecific bands. (b) LBW242 also fails to degrade cIAP2 at later time points $(24 \mathrm{~h})$. (c) DKO ${ }^{\mathrm{i}-\mathrm{CIAP} 1}$ MEFs that inducibly express cIAP1 were used to assess whether SMs stimulate cIAP1 degradation in the absence of cIAP2. cIAP1 expression was induced with $10 \mathrm{nM}$ 4-hydroxy-tamoxifen for $16 \mathrm{~h}$, followed by treatment with $1 \mu \mathrm{M}$ LBW242 for the indicated time points. (d-f) ClAP2 expression was induced with Dox for $16 \mathrm{~h}$ after which cells were analysed. (d) Biotinylated SM was used to purify SM-binding proteins from lysates of the indicated MEFs. Asterisks indicate nonspecific bands. (e) CIAP2 readily promotes ubiquitylation of RIP1 in complex-I after TNF $\alpha$ stimulation. DKO-clAP1 MEFs were left untreated or treated with Dox to induce CIAP2 expression, and complex-I was purified using FLAG-tagged TNF $\alpha$. Co-purified proteins were analysed by immunoblotting. (f) Induced expression of cIAP2 results in suppression of p100 cleavage. (g) clAP1 and cIAP2 are capable of targeting NIK for degradation. NIK was co-transfected with GFP, cIAP1 or cIAP2 in 293T cells

refractory to SM-mediated degradation, SM treatment did not diminish the ability of clAP2-MALT1 to promote NF- $\kappa$ B activation (Figure 4d). Taken together, these data indicate that the RING finger of CIAP2, although unable to promote auto-ubiquitylation, is nevertheless required for SM-induced and cIAP1-mediated degradation of ClAP2.

Depletion of cIAP1 results in NF- $k$ B-dependent induction of cIAP2 gene expression in cancer cells. The observation that SM-induced degradation of clAP2 is ineffective in the absence of clAP1 has important ramifications as it predicts that SM treatment will be unsuccessful under conditions in which CIAP1 is absent and ClAP2 is expressed to high levels. To investigate the efficiency of SM compounds in cancer cells, we used HT1080 fibrosarcoma cells (Figure 5a). Treatment with LBW242 led to efficient degradation of both CIAP1 and clAP2 within the hour. However, at $24 \mathrm{~h}$, clAP2 levels dramatically increased and were significantly higher compared with controls (Figure 5a), whereas cIAP1 levels remained undetectable. Re-challenging cells with the SM after the initial treatment did not induce clAP2 degradation at 


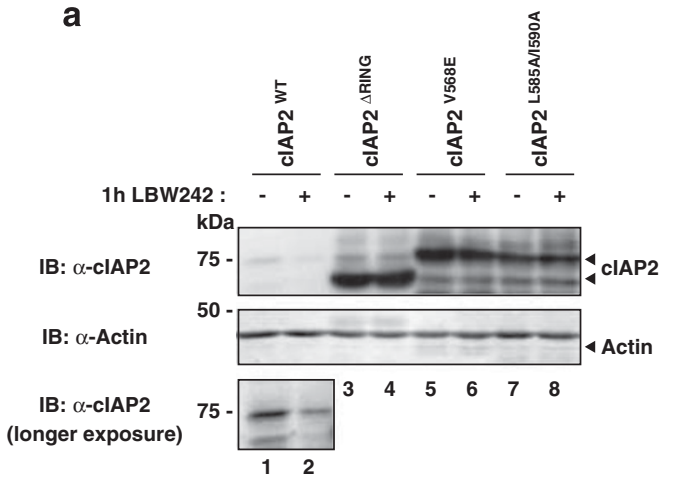

b

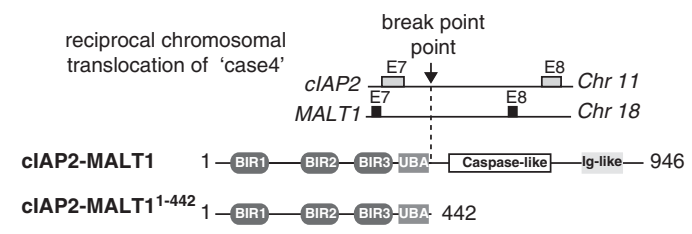

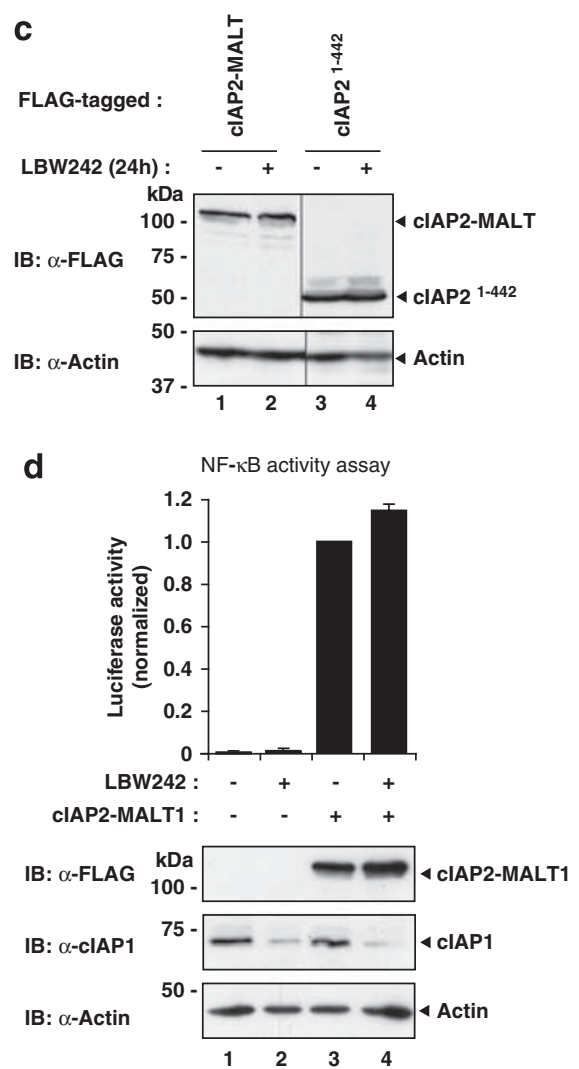

Figure 4 SMs fail to stimulate degradation of cIAP2-MALT1. (a) Wild-type cIAP2, but not the RING-finger mutants cIAP2 ${ }^{\triangle \mathrm{RING}}, \mathrm{ClAP} 2^{\mathrm{V} 568 \mathrm{E}}$ and cIAP2 ${ }^{\mathrm{L585A} / 590 \mathrm{~A}}$, is degraded by LBW242. CIAP2 $^{\triangle \mathrm{RING}}$ lacks the C-terminal RING-finger domain, whereas cIAP2 ${ }^{\mathrm{V} 568 \mathrm{E}}$ and CIAP2 ${ }^{\mathrm{L585A} / 590 \mathrm{~A}}$ carry point mutations that abrogate RING dimerisation and E2 binding, respectively. HEK293T cells were transiently transfected with plasmids expressing the indicated constructs. After $24 \mathrm{~h}$, cells were either left untreated or incubated with $1 \mu \mathrm{M}$ LBW242. (b) Schematic representation of the constructs used. (c) HEK293T cells were transiently transfected with plasmids expressing FLAG-cIAP2MALT1 or FLAG-CIAP2 ${ }^{\mathrm{N}-\text { Term }}$ (amino acids 1-442). The experiment was conducted as described in a. (d) Expression of clAP2-MALT1 induces NF- $\kappa B$ activation that is resistant to SM intervention. cIAP2-MALT1 was co-transfected with a NF- $k$ B reporter plasmid in HEK293T cells. Luciferase activity was expressed relative to untreated controls. Data represent the mean of three independent experiments, and the error bars indicate S.D. of triplicates

$24 \mathrm{~h}$, ruling out the possibility that the compound became ineffective at later time points (Figure 5a). SM-induced upregulation of clAP2 seems to be a common phenomena as it is also seen in several other cancer cell lines, such as MDA-MB-231 (breast cancer), A2058 and Me4405 (melanoma) (Figures $5 b$ and $c$ ).

Induction of clAP2 not only occurred after SM treatment but also in response to RNAi-mediated knockdown of clAP1 (Figures $5 \mathrm{~d}$ and e). Moreover, it also induced expression of a cIAP2-Luciferase (clAP2-Luc) reporter gene (Figures 5f) containing NF- $\kappa \mathrm{B}$-binding sites of the clAP2 promoter region. ${ }^{32}$ Similarly, knockdown of TRAF2 also induced expression of the CIAP2-LUC reporter. Transcriptional induction of $c I A P 2$ was dependent on the non-canonical NF- $\kappa \mathrm{B}$ pathway as simultaneous depletion of NIK suppressed induction of clAP2 gene expression (Figure 5f). Under the same conditions, knockdown of RIP1 had no effect. Like RNAi-mediated depletion of clAP1, SM-induced degradation of clAP1 also caused activation of non-canonical NF- $\kappa \mathrm{B}$ signalling in BE and HT1080 cells (Figures $5 \mathrm{~g}$ and $\mathrm{h}$, see the Materials and Methods section for details). LBW242mediated induction of clAP2 expression was clearly NF- $\kappa \mathrm{B}$ dependent as the expression of $I_{\kappa} \mathrm{B}-\mathrm{SR}$ suppressed $\mathrm{ClAP2}$ Luc reporter activity (Figure $5 \mathrm{i}$ and Supplementary Figure S1) and clAP2 protein expression (Figure 5j). In agreement with the notion that clAP2 expression is under the transcriptional control of $\mathrm{NF}-\kappa \mathrm{B},{ }^{33}$ we observed strong induction of the CIAP2-LUC reporter and ClAP2 protein expression upon treatment with TNF $\alpha$ and LIGHT or NIK expression (Figure 5i, and Supplementary Figures S1 and S4), as well as LBW242 treatment (Figure 5j). These data are consistent with previous reports showing that loss of clAP1 leads to ectopic activation of the non-canonical NF- $\kappa$ B pathway, ${ }^{11,12,14,17}$ which in turn leads to upregulation of clAP2. Interestingly, although the loss of cIAP1 by SM treatment leads to a modest stabilisation of NIK protein levels in HT1080 WT cells, levels of NIK are significantly higher in SM-treated $\mathrm{HT} 1080^{\mathrm{l} \kappa \mathrm{B}-\mathrm{SR}}$ cells that cannot induce clAP2 (Figure 5j). This is consistent with the notion that clAP2 functions as the E3 ligase for NIK, targeting NIK for degradation even in the absence of clAP1. Moreover, these data also suggest that induction of clAP2 serves as a negative feedback mechanism that dampens non-canonical NF- $\kappa \mathrm{B}$ signalling through degrading NIK.

SM-induced upregulation of cIAP2 dampens TNF $\alpha$ killing. As depletion of clAP1 results in compensatory upregulation of clAP2, we tested whether clAP2 can modulate the sensitivity to TNF $\alpha$-induced cell death. First, 

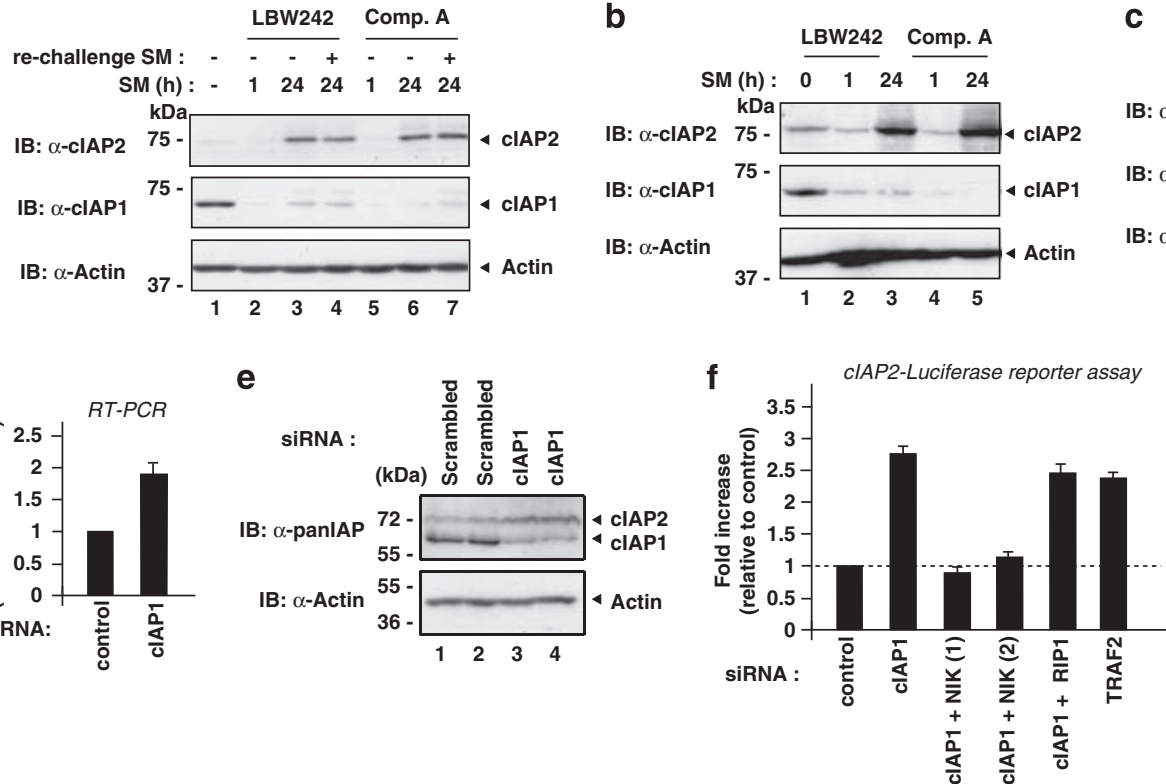

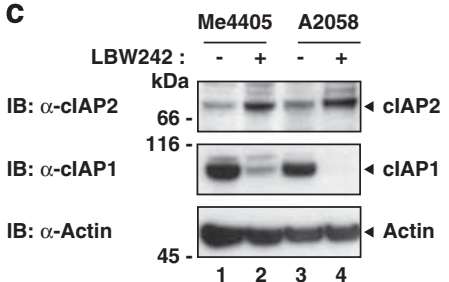

g

cIAP2-Luciferase reporter assay

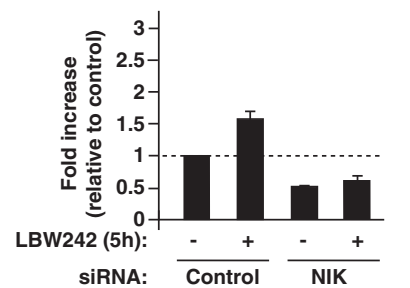

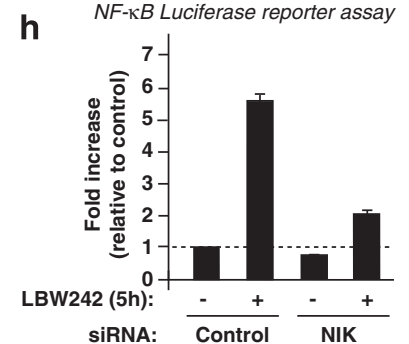
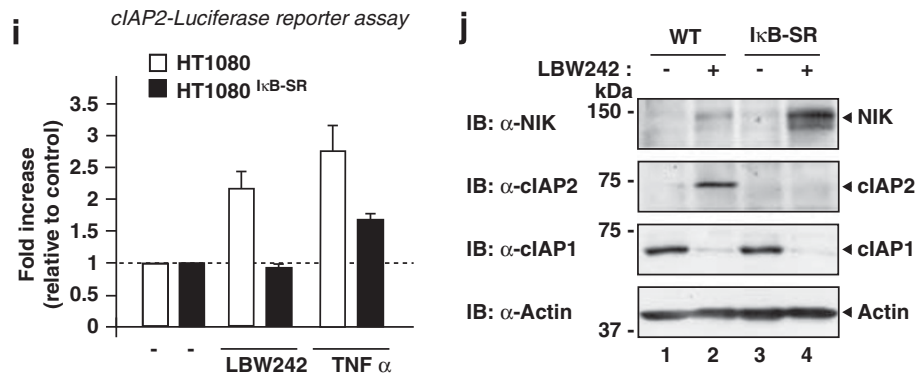

Figure 5 Treatment with SMs results in the upregulation of cIAP2 by non-canonical activation of NF- $\kappa$ B. (a-c) cIAP2 protein levels increase after prolonged treatment with the SM. (a) HT1080 cells were incubated with $1 \mu \mathrm{M}$ LBW242 or $100 \mathrm{nM}$ Comp. A for the indicated time points. One hour before harvesting and lysing cells, fresh SM compounds were added (re-challenged) in the indicated lanes (LBW242 in lane and Comp. A in lane). (b) MDA-MB-231 cells were treated with $1 \mu \mathrm{M}$ LBW242 or $100 \mathrm{nM}$ of Comp. A for the indicated time points. (c) Me4405 and A2058 cells were treated for $16 \mathrm{~h}$ with $100 \mathrm{nM}$ of Comp. A. (d) Cells were transfected with the indicated siRNA oligos, harvested and lysed 2 days after transfection. (e) cIAP2 mRNA levels increase upon clAP1 depletion. BE cells were transfected with the indicated siRNA oligos and analysed after $48 \mathrm{~h}$ using quantitative RT-PCR. (f and $\mathbf{g}$ ) SM treatment and siRNA-mediated depletion of clAP1 and TRAF2 result in the activation of non-canonical $\mathrm{NF}_{\kappa} \mathrm{B}$ signalling and induction of $C / A P 2$ gene expression in $\mathrm{BE}$ cells. Cells stably expressing a luciferase reporter under the control of the $c / A P 2$ promoter (cIAP2-Luc) were transfected with the indicated siRNA oligos and analysed for luciferase activity $48 \mathrm{~h}$ later. (h) SM treatment results in NIK-dependent activation of NF- $\kappa \mathrm{B}$. HT1080 cells stably expressing a NF- $\kappa$ B luciferase reporter were transfected with the indicated siRNA oligos and analysed for luciferase activity $48 \mathrm{~h}$ later. (i and j) SM- and TNF $\alpha$-mediated induction of ClAP2 expression is NF- $\kappa$ B dependent. (i) $\mathrm{HT} 1080$ and $\mathrm{HT} 1080^{\mathrm{k} K \mathrm{~B}-\mathrm{SR}}$ cells, which express a non-degradable form of $\mathrm{I}_{\kappa} \mathrm{B}$, were transfected with the CIAP2-Luc reporter plasmid and left untreated or treated with the indicated combinations. (j) Inhibition of SM-mediated induction of clAP2 results in elevated levels of NIK. HT1080 and HT1080 ${ }^{\mathrm{kB}-\mathrm{SR}}$ cells were left untreated or treated with $1 \mu \mathrm{M}$ LBW242 for $16 \mathrm{~h}$

we investigated the ability of clAP2 to suppress TNF $\alpha$ induced cell death independently of clAP1. Indeed, when clAP2 expression was induced in reconstituted cIAP1/2 DKO MEFs, these cells were completely protected from the cytotoxic effects of TNF $\alpha$ (Figures $6 a$ and b). Moreover, although coordinated knockdown of clAP1 and clAP2 sensitised BE colon cancer cells to $T N F \alpha$, expression of an RNAi-resistant clAP2 rescue construct provided significant protection from TNF $\alpha$ killing (Figure 6c).

Although several cancer cell lines are sensitive to SM, most cancer cell lines, such as HT1080 and BE cells, are resistant. Such 'SM-resistant cells' stay alive because they fail to produce autocrine TNF $\alpha$. However, when supplied with exogenous TNF $\alpha$, these cells also rapidly succumb to TNFR1-mediated apoptosis. Consistent with the notion that induced expression of clAP2 protects from the lethal effects of TNF $\alpha$, we find that RNAi-mediated knockdown of clAP2 (Figure 6d) increased sensitivity to TNF $\alpha$ killing upon SM treatment (Figure 6e and Supplementary Figure S5). This is consistent with a previous report demonstrating that clAP2 provides resistance to SM treatment. ${ }^{19}$ Moreover, clAP1/2 DKO MEFs were significantly more sensitive to $\operatorname{TNF} \alpha$ than singly clAP1 $^{-1-}$ MEFs (Figures $6 f$ and $g$ ). Taken together, these data indicate that the expression of clAP2 is refractory to degradation by SM in the absence of $\operatorname{clAP1}$, and that the induced expression of clAP2 can provide protection from the lethal effects of $T N F \alpha$.

\section{Discussion}

The realisation that members of the IAP family are frequently deregulated in cancer and contribute to chemoresistance and 
a

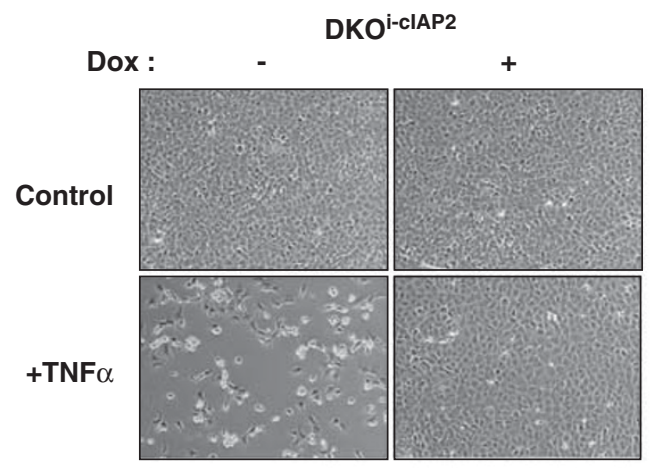

C

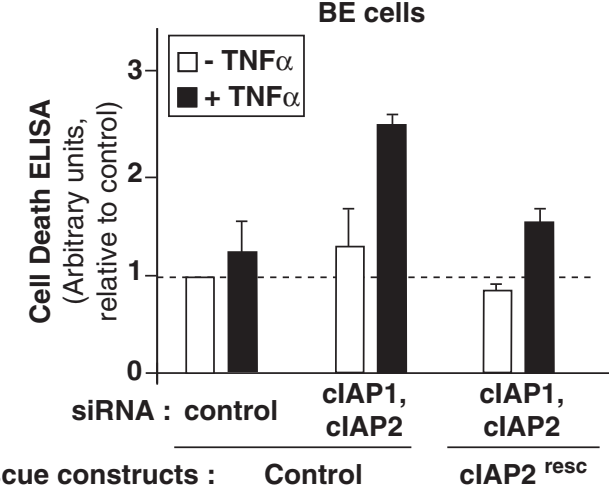

b
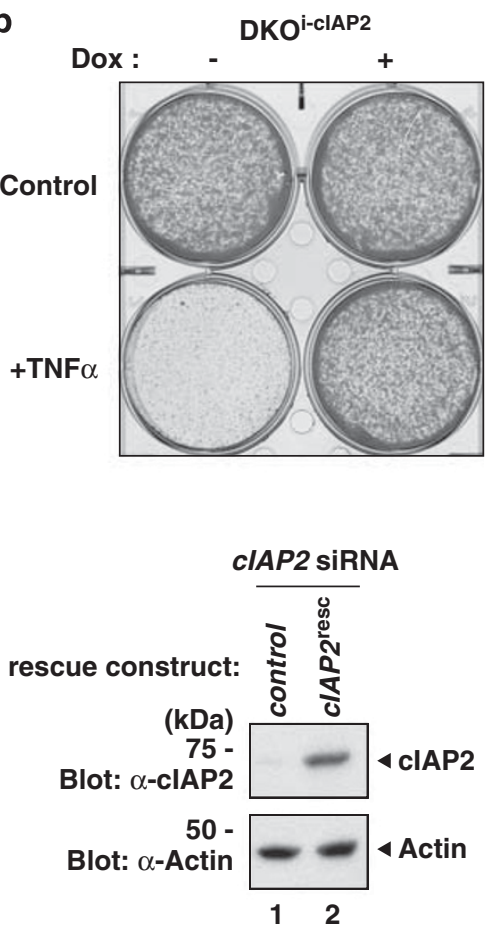

d

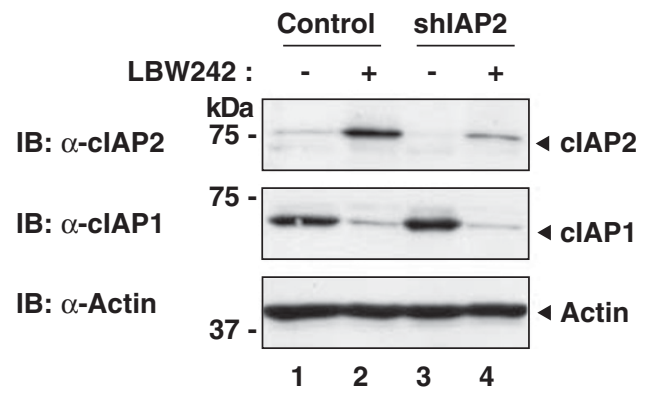

e

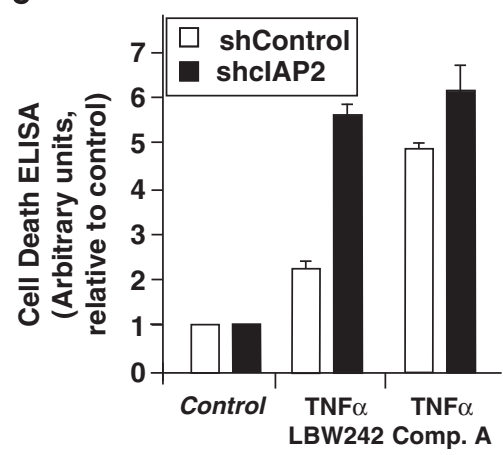

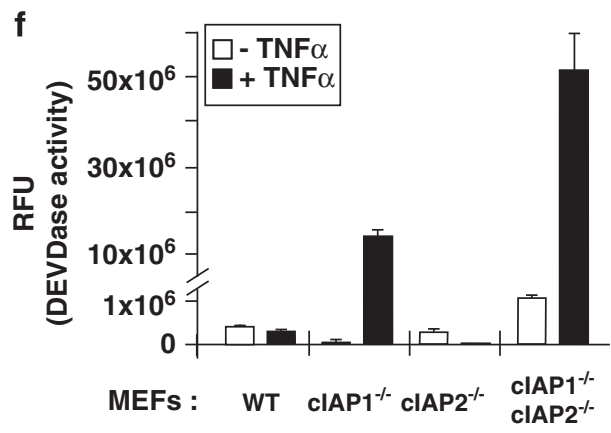

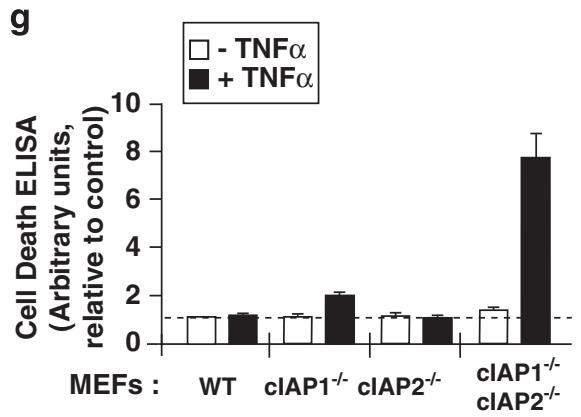

Figure 6 Induction of clAP2 provides resistance to SM-induced TNF $\alpha$ killing in cancer cells. (a and $\mathbf{b})$ Induced expression of clAP2 protects cells against TNF $\alpha$-mediated cell death in the absence of cIAP1. (a) Light micrographs showing the overall morphology of DKO ${ }^{\text {i-clAP2 }}$ MEFs treated with the indicated combinations. (b) Clonogenic survival assay. Cells were visualised using crystal violet. (c) BE cells, stably expressing either a control plasmid or siRNA-resistant cIAP2 (cIAP2resc), were transfected with the indicated siRNA oligos. After $48 \mathrm{~h}$, cells were left untreated or treated with TNF $\alpha$ for $18 \mathrm{~h}$. Cell death was assayed using Cell Death ELISA (Roche Applied Science, Penzburg, Germany) (measuring the amount of cleaved DNA-histone complexes (nucleosomes) in the cytoplasm; left panel). clAP2 expression of the RNAi-resistant rescue construct was examined by immunoblotting the lysates with an anti-cIAP2 antibody (right panel, lane 2). (d and e) RNAi-mediated knockdown of clAP2 increases sensitivity to TNF $\alpha$ killing upon SM treatment. HT1080 cells stably expressing either a control shRNA or shclAP2 were either left untreated or treated with SM for $16 \mathrm{~h}$. (d) The expression of CIAP2 was analysed by immunoblotting. (e) Cell Death ELISA of $\mathrm{HT} 1080^{\text {shControl }}$ and $\mathrm{HT} 1080^{\text {shclAP2 }}$ cells treated with the indicated combinations. (f and g) clAP1/2 DKO MEFs are significantly more sensitive to TNF $\alpha$ than singly clAP1 ${ }^{-1-}$ MEFs. The indicated MEFs were exposed to TNF $\alpha$, and caspase activity and apoptosis were determined using DEVDase assays (f) and Cell Death ELISA (g) 
treatment failure ${ }^{34}$ has sparked renewed interest in the development of small pharmacological inhibitors of IAPs. Consistent with the notion that different types of cancer cells are addicted to IAPs for their survival, inactivation of IAPS, particularly when combined with other treatments, results in the death of many tumour cells. ${ }^{11,12,17,35-37}$ However, a key problem in the treatment of cancer is the identification of tumours that are susceptible to a particular treatment. Moreover, development of resistance represents a major challenge in the fight against cancer. Hence, a better understanding of the mechanisms through which SM compounds exert their activities will be essential for the right choice of target patients, and to limit the likelihood of resistance development.

In this study, we have addressed the molecular mechanism through which SMs exercise their IAP-inhibitory activity. Surprisingly, we find that SM-induced degradation of clAP1 and clAP2 is dependent on TRAF2 binding. Although TRAF2 is essential for clAP degradation, and carries a RING-finger domain, it does not function as the E3 ligase for clAPs. This is evident because the RING-finger domain of TRAF2 is dispensable for SM-induced degradation of clAP1. This notion is also consistent with recent structural studies indicating that the RING of TRAF2 is inactive because it lacks key residues required for E2 binding. ${ }^{38}$ Moreover, although TRAF2/TRAF5 are required for $\mathrm{TNF} \alpha$-mediated NF- $\kappa$ B activation, their RING fingers, and hence their activity as E3 ligases, are dispensable. $^{20}$ Therefore, TRAF2 merely seems to fulfil a scaffolding function supporting the E3 ligase activity of clAPs.

Recent evidence has indicated that SMs stimulate dimerisation of the RING domains of cIAPs, which in turn is required to promote discharging of Ub from the nascent E2. ${ }^{26}$ Therefore, TRAF2 is likely to function as a binding platform that facilitates dimerisation of the RING domains of clAPs. Intriguingly, structural and biochemical studies indicate that a single clAP1 molecule binds the trimeric TRAF2 coiled-coil domain. ${ }^{39,40}$ As only one IAP molecule binds to each TRAF2 trimer, one is left speculating how clAP1 RING dimer formation is actually achieved. One possible scenario is that in vivo TRAFs form higher-order oligomers.

Although degradation of clAP1 depends on TRAF2, degradation of clAP2 requires both TRAF2 and ClAP1. In the absence of clAP1 or TRAF2, clAP2 is no longer depleted by SM treatment. Although clAP2 promotes ubiquitylation of RIP1 and NIK in the absence of cIAP1 (Figures $3 d-f$ ), it seems to be unable to target itself for degradation. Interestingly, clAP2's own RING finger is essential for SM-induced degradation of clAP2. The requirement of clAP2's own RING finger suggests a model in which the RING finger of clAP2 heterodimerises with the one of clAP1 to promote ubiquitylation of clAP2.

The observation that SM-induced degradation of clAP2 requires clAP1 has significant implications as it predicts that SM treatment will be less effective in cancers that lack clAP1 and express high levels of clAP2. Importantly, loss of clAP1 not only removes the E3 ligase for clAP2 but also results in deregulated activation of non-canonical NF- $\kappa$ B signalling, which in turn leads to induction of $c / A P 2$ gene expression. The NF- $\kappa \mathrm{B}-$ dependent increase in the levels of clAP2 protein decreases the sensitivity of cancer cells to SM and TNF $\alpha$-induced apoptosis. ${ }^{19}$
Consistent with the notion that clAP2 protects from the lethal effects of TNF $\alpha$, depletion of cIAP2 renders cancer cells more susceptible to treatment with TNF $\alpha$ and SM. Similarly, clAP1/2 DKO MEFs are also significantly more sensitive to $\mathrm{TNF} \alpha$ than singly clAP1 $^{-1-}$ MEFs.

Induced expression of clAP2 seems to protect cells from the lethal effects of TNF $\alpha$ by two distinct mechanisms: First, after TNF-R1 engagement, it promotes the ubiquitylation of components of complex-I, such as RIP1, thereby limiting the formation of a secondary, RIP1-dependent death-inducing complex. Second, clAP2 also seems to protect cells by targeting NIK for degradation. This decreases the constitutive activation of non-canonical NF- $\kappa \mathrm{B}$ signalling that drives the production of autocrine TNF $\alpha$.

The identification of potential mechanisms through which cancer cells can resist SM treatment will not only help to choose patient populations that will respond to the SM but also device better treatment combinations that boost treatment sensitivity. As clAP2 gene induction critically depends on NF$\kappa \mathrm{B}$ signalling, combined treatments of SM and IKK inhibitors, which block activation of $\mathrm{NF}-\kappa \mathrm{B}$ activation, are promising avenues that are expected to dramatically improve treatment outcome and patient survival.

\section{Materials and Methods}

Reagents, constructs and antibodies. AC-DEVD-AMC was purchased from Sigma-Aldrich (St. Louis, MO, USA), and recombinant human and mouse TNF $\alpha$ were obtained from R\&D Systems (Minneapolis, MN, USA) and Enzo Life Sciences (Farmingdale, NY, USA), respectively. Constructs were generated in pcDNA3 (Invitrogen, Carlsbad, CA, USA) or pEF6 (Invitrogen) using PCR and confirmed by DNA sequencing. The episomal pCEP-1400-Luciferase reporter construct was created by replacing the CMV promoter with a fragment containing the $C I A P 2$ promoter driving luciferase expression. The CIAP2-Luc insert was taken from pGL2-1400 that was kindly provided by Lee Tae. siRNA-resistant CIAP2 (pCEP4-based) was generated by introducing silent point mutations that impair siRNA-mediated knockdown. Sequence information can be obtained on request. The following antibodies were used: $\alpha$-actin (Santa Cruz Biotechnology, Santa Cruz, CA, USA), $\alpha$-cIAP1, $\alpha$-cIAP2 (Enzo Life Sciences), $\alpha$-panIAP (R\&D Systems), $\alpha$-TRAF2 (Santa Cruz Biotechnology and Calbiochem, San Diego, CA, USA), $\alpha$-NIK (Cell Signaling, Danvers, MA, USA), $\alpha$-FLAG (Sigma) and $\alpha-p 100$ (Cell Signaling).

Tissue culture and RNAi. Transfections of HEK293T cells were performed using Effectene transfection reagent (Qiagen, Hilden, Germany) according to the manufacturer's instructions. The BE colon cancer cell line and $\mathrm{HT} 1080^{\mathrm{I} \kappa \mathrm{B}-\mathrm{SR}}$ were kindly provided by $C$ Marshall (ICR, London) and Olivier Micheau (Dijon, France), respectively. Single and DKO MEFs were generated as described previously. ${ }^{11}$ siRNA duplexes were purchased from Ambion (Austin, TX, USA) and Qiagen. Cells were transfected with siRNA oligos at $50 \mathrm{nM}$ final concentration using Hiperfect (Qiagen) according to the manufacturer's instructions.

Generation of stable cells by lentiviral infection. For reconstitution of TRAF2 ${ }^{-l-}$ MEFs, TRAF2 ${ }^{-l-}$ MEFs were first infected with pFU-Gal4-VP16-PGKhygro lentivirus. Selected stable cells were subsequently infected with lentivirus containing the relevant $\mathrm{pF}-5 \times \mathrm{XUAS}$ plasmids (TRAF2 ${ }^{\mathrm{WT}}$ and mutants). To generate cells carrying $I_{\kappa} \mathrm{B}-\mathrm{SR}$, i-clAP2, shclAP2 or shControl, pTRIPZ-based derivatives (Open Biosystems, Huntsville, AL, USA) were used. To generate 293-FLPin ${ }^{\text {shclAP1/ }}$ i-cIAP2 cells, 293-TRex-FLPin cells (Invitrogen) were infected using lentivirus with shclAP1-pTRIPZ (Open Biosystems). A stable clone was chosen and knockdown of CIAP1 was verified by immunoblotting. This clone was subsequently transfected with pcDNA5.1-cIAP2 (i-clAP2) and stable cells were selected using hygromycin. Reconstitution (knockdown of clAP1 and expression of clAP2) was induced in the presence of $100 \mathrm{ng} / \mathrm{ml}$ doxocycline for at least $48 \mathrm{~h}$.

In vitro ubiquitylation assay. In vitro ubiquitylation assays were performed in the ubiquitylation buffer (containing $40 \mathrm{mM}$ Tris- $\mathrm{HCl} \mathrm{pH}(7.5), 10 \mathrm{mM} \mathrm{MgCl}$, 
$0.6 \mathrm{mM}$ DTT) in the presence of $2 \mathrm{mM} \mathrm{ATP}, 20 \mu \mathrm{g} \mathrm{Ub}, 0.5 \mu \mathrm{g}$ human $\mathrm{E} 1,1 \mu \mathrm{g}$ $\mathrm{UbcH} 5 \mathrm{c}$ and variable amounts of CIAP1 or TRAF2. Reactions were performed at $37^{\circ} \mathrm{C}$ for $1 \mathrm{~h}$ and stopped by boiling in the sample buffer.

Luciferase assays. The $\mathrm{pSL}-\mathrm{NF} \kappa \mathrm{B}$-Luc reporter plasmid (Clontech, Mountainview, CA, USA) was used for the secreted luciferase assay. Twentyfour hours after transfection, cells were split in two and either left uninduced or induced with doxocycline $(100 \mu \mathrm{g} / \mathrm{ml})$. Twenty-four hours later, the medium was replaced and cells were left for a further $24 \mathrm{~h}$, after which Luciferase secretion was assayed using the Ready-To-Glow Secreted Reporter System (Clontech) according to the manufacturer's instructions. The cIAP2-Luciferase assay was performed as described previously. ${ }^{41} \mathrm{BE}$ stable cells were generated using the pCEP4[-1.4kLuc/ cIAP2- promoter]. pCEP4 is an episomal expression vector that is maintained at few copies per cell (Invitrogen).

Biotinylated SM pull-downs. Cells were lysed using $1 \%$ Triton lysis buffer (10 mM Tris (pH7.5), $150 \mathrm{mM} \mathrm{NaCl}, 10 \%$ glycerol and 1\% Triton) containing $50 \mathrm{mM}$ chloroacetimide. Lysates were cleared by centrifugation, split in two and incubated either with streptavidin sepharose beads (GE Healthcare, Little Chalfont, UK) only or with beads pre-bound with $200 \mathrm{nM}$ biotinylated SM. After $1 \mathrm{~h}$ incubation at room temperature, the supernatant was removed and beads were washed 4 times with the IPPG50 wash buffer. Co-purified proteins were eluted by boiling in $2 \times$ Laemmli sample buffer.

Real-time RT-PCR. Total RNA was isolated using the RNAase mini kit (Qiagen) according to the manufacturer's instructions. CDNA was synthesised from total RNA using QuantiTech Reverse Transcription (Qiagen) according to the manufacturer's instructions. Quantitative real-time RT-PCR reactions were performed using SYBR Green (Eurogentec, Seraing, Belgium). Relative mRNA levels were calculated after normalisation to GAPDH using the DDCt method.

Cell death assays. Cell death was analysed by using the Cell Death Detection ELISA ${ }^{\text {PLUS }}$ kit (Roche) according to the manufacturer's instructions. For clonogenic assays, cells were washed with PBS, and $1-5 \%$ of cells were re-plated. Cells were cultured until the control plates were confluent. Viable cells were fixed in $3.7 \%$ formaldehyde/PBS and stained with $0.5 \%$ crystal violet/PBS. For quantification, plates were air dried and decolourised with a destaining solution (containing $0.5 \%$ SDS, $0.5 \%$ ethanol, $0.5 \mathrm{M}$ TRIS- $\mathrm{Cl}$, pH 7.6) for $1 \mathrm{~h}$ after which OD $586 \mathrm{~nm}$ was measured. For DEVDase assay, cells were lysed in $1 \%$ Triton lysis buffer and cleared by centrifugation. The supernatant was added to the DEVDase assay mix (20 $\mu$ M DEVD-AMC (Calbiochem), $2 \mathrm{mM} \mathrm{DTT,} 10 \mathrm{mM}$ Tris (pH 7.5), $150 \mathrm{mM} \mathrm{NaCl}$, $0.1 \%$ Triton and $5 \%$ glycerol). Reactions were analysed at $380 \mathrm{nM}$ excitation and $460 \mathrm{nM}$ emission.

\section{Conflict of interest}

Christopher Benetatos is an employee of TetraLogic Pharmaceuticals.

Acknowledgements. We thank the members of the Apoptosis Lab for support and critical reading of this manuscript. We are indebted to Leigh Zawel and Novartis for LBW242 and TetraLogic for Comp. A and Comp. C. Furthermore, we also thank Xiaodong Wang for the biotinylated SM, Olivier Micheau for the HT1080 ${ }^{1 \kappa \mathrm{B}-\mathrm{SR}}$ cells and Lee Tae for the pGL2-1400 construct. We acknowledge NHS funding to the NIHR Biomedical Research Centre.

1. Chen DJ, Huerta S. Smac mimetics as new cancer therapeutics. Anticancer Drugs 2009; 20: $646-658$

2. Vaux DL, Silke J. Mammalian mitochondrial IAP binding proteins. Biochem Biophys Res Commun 2003; 304: 499-504.

3. Cossu F, Mastrangelo E, Milani M, Sorrentino G, Lecis D, Delia D et al. Designing Smac-mimetics as antagonists of XIAP, clAP1, and clAP2. Biochem Biophys Res Commun 2009; 378: 162-167.

4. Yang YL, Li XM. The IAP family: endogenous caspase inhibitors with multiple biological activities. Cell Res 2000; 10: 169-177.

5. Gyrd-Hansen M, Darding M, Miasari M, Santoro MM, Zender L, Xue W et al. IAPs contain an evolutionarily conserved ubiquitin-binding domain that regulates NF-I[kappa]|B as well as cell survival and oncogenesis. Nat Cell Biol 2008; 10: 1309-1317.

6. Blankenship JW, Varfolomeev E, Goncharov T, Fedorova AV, Kirkpatrick DS, Izrael-Tomasevic A et al. Ubiquitin binding modulates IAP antagonist-stimulated proteasomal degradation of C-IAP1 and C-IAP2(1). Biochem J 2009; 417: 149-160.

7. Pop C, Salvesen GS. Human caspases: activation, specificity, and regulation. J Biol Chem 2009; 284: 21777-21781.
8. Vallabhapurapu S, Matsuzawa A, Zhang W, Tseng PH, Keats JJ, Wang $\mathrm{H}$ et al. Nonredundant and complementary functions of TRAF2 and TRAF3 in a ubiquitination cascade that activates NIK-dependent alternative NF-kappaB signaling. Nat Immunol 2008; 9: 1364-1370.

9. Bertrand M, Milutinovic S, Dickson K, Ho W, Boudreault A, Durkin J et al. cIAP1 and cIAP2 facilitate cancer cell survival by functioning as E3 ligases that promote RIP1 ubiquitination. Mol Cell 2008; 30: 689-700.

10. Varfolomeev E, Goncharov T, Fedorova AV, Dynek JN, Zobel K, Deshayes K et al. c-IAP1 and C-IAP2 are critical mediators of tumor necrosis factor alpha (TNFalpha)-induced NF-kappaB activation. J Biol Chem 2008; 283: 24295-24299.

11. Vince J, Wong W, Khan N, Feltham R, Chau D, Ahmed A et al. IAP antagonists target clAP1 to induce TNFalpha-dependent apoptosis. Cell 2007; 131: 682-693.

12. Varfolomeev E, Blankenship J, Wayson S, Fedorova A, Kayagaki N, Garg P et al. IAP antagonists induce autoubiquitination of c-IAPs, NF-kappaB Activation, and TNFalphadependent apoptosis. Cell 2007; 131: 669-681.

13. Mahoney D, Cheung H, Mrad R, Plenchette S, Simard C, Enwere E et al. Both ClAP1 and cIAP2 regulate TNF\{alpha\}-mediated NF-\{kappa\}B activation. Proc Natl Acad Sci USA 2008; 105: 11778-11783.

14. Gaither A, Porter D, Yao Y, Borawski J, Yang G, Donovan J et al. A Smac mimetic rescue screen reveals roles for inhibitor of apoptosis proteins in tumor necrosis factor-alpha signaling. Cancer Res 2007; 67: 11493-11498.

15. Bonizzi G, Karin M. The two NF-kappaB activation pathways and their role in innate and adaptive immunity. Trends Immunol 2004; 25: 280-288.

16. Bianchi K, Meier P. A tangled web of ubiquitin chains: breaking news in TNF-R1 signaling. Mol Cell 2009; 36: 736-742.

17. Petersen S, Wang L, Yalcin-Chin A, Li L, Peyton M, Minna J et al. Autocrine TNFalpha signaling renders human cancer cells susceptible to Smac-mimetic-induced apoptosis. Cancer Cell 2007; 12: 445-456.

18. Wong W, Gentle I, Nachbur U, Anderton H, Vaux D, Silke J. RIPK1 is not essential for TNFR1-induced activation of NF-kappaB. Cell Death Differ 2009; 17: 482-487.

19. Petersen SL, Peyton M, Minna JD, Wang X. Overcoming cancer cell resistance to Smac mimetic induced apoptosis by modulating clAP-2 expression. Proc Natl Acad Sci USA 2010; 107: 11936-11941.

20. Vince J, Pantaki D, Feltham R, Mace P, Cordier S, Schmuckle A et al. TRAF2 must bind to cIAPs for TNF to efficiently activate NF-\{kappa\}B and to prevent TNF-induced apoptosis. J Biol Chem 2009; 284: 35906-35915.

21. Samuel T, Welsh K, Lober T, Togo S, Zapata J, Reed J. Distinct BIR domains of clAP1 mediate binding to and ubiquitination of tumor necrosis factor receptor-associated factor 2 and second mitochondrial activator of caspases. J Biol Chem 2006; 281 : 1080-1090.

22. Varfolomeev E, Wayson SM, Dixit VM, Fairbrother WJ, Vucic D. The inhibitor of apoptosis protein fusion c-IAP2.MALT1 stimulates NF-kappaB activation independently of TRAF1 AND TRAF2. J Biol Chem 2006; 281: 29022-29029.

23. Zarnegar BJ, Wang Y, Mahoney DJ, Dempsey PW, Cheung HH, He J et al. Noncanonical NF-kappaB activation requires coordinated assembly of a regulatory complex of the adaptors CIAP1, cIAP2, TRAF2 and TRAF3 and the kinase NIK. Nat Immunol 2008; 9: 1371-1378.

24. Grech AP, Amesbury M, Chan T, Gardam S, Basten A, Brink R. TRAF2 differentially regulates the canonical and noncanonical pathways of NF-kappaB activation in mature $B$ cells. Immunity 2004; 21: 629-642.

25. Gardam S, Sierro F, Basten A, Mackay F, Brink R. TRAF2 and TRAF3 signal adapters act cooperatively to control the maturation and survival signals delivered to $B$ cells by the BAFF receptor. Immunity 2008; 28: 391-401.

26. Feltham R, Moulin M, Vince JE, Mace PD, Wong WW, Anderton $\mathrm{H}$ et al. Tumor necrosis factor (TNF) signaling, but not TWEAK (TNF-like weak inducer of apoptosis)-triggered clAP1 (cellular inhibitor of apoptosis protein 1) degradation, requires CIAP1 RING dimerization and E2 binding. J Biol Chem 2010; 285: 17525-17536.

27. Mace $P$, Linke K, Feltham R, Schumacher F, Smith C, Vaux D et al. Structures of the clAP2 ring domain reveal conformational changes associated with E2 recruitment. J Biol Chem 2008; 283: 31633-31640.

28. Conze D, Albert L, Ferrick D, Goeddel D, Yeh W, Mak T et al. Posttranscriptional downregulation of C-IAP2 by the ubiquitin protein ligase C-IAP1 in vivo. Mol Cell Biol 2005; 25: 3348-3356.

29. Wang $L$, Du F, Wang $X$. TNF-alpha induces two distinct caspase-8 activation pathways. Cell 2008; 133: 693-703.

30. Isaacson PG, Du M-Q. Gastrointestinal lymphoma: where morphology meets molecular biology. J Pathol 2005; 205: 255-274.

31. Zhou H, Du M-Q, Dixit VM. Constitutive NF-kappaB activation by the $t(11 ; 18)(q 21 ; q 21)$ product in MALT lymphoma is linked to deregulated ubiquitin ligase activity. Cancer Cell 2005; 7: 425-431.

32. Hong SY, Yoon WH, Park JH, Kang SG, Ahn JH, Lee TH. Involvement of two NF-kappa B binding elements in tumor necrosis factor alpha-, CD40-, and Epstein-Barr virus latent membrane protein 1-mediated induction of the cellular inhibitor of apoptosis protein 2 gene. J Biol Chem 2000; 275: 18022-18028.

33. Wang C-Y, Mayo M, Korneluk R, Goeddel D, Baldwin A. NF-B antiapoptosis: induction of TRAF1 and TRAF2 and C-IAP1 and c-IAP2 to suppress caspase-8 activation. Science 1998; 281: 1680 
34. Hunter AM, LaCasse EC, Korneluk RG. The inhibitors of apoptosis (IAPs) as cancer targets. Apoptosis 2007; 12: 1543-1568.

35. McManus DC, Lefebvre CA, Cherton-Horvat G, St-Jean M, Kandimalla ER, Agrawal S et al. Loss of XIAP protein expression by RNAi and antisense approaches sensitizes cancer cells to functionally diverse chemotherapeutics. Oncogene 2004; 23: 8105-8117.

36. Hu Y, Cherton-Horvat G, Dragowska V, Baird S, Korneluk RG, Durkin JP et al. Antisense oligonucleotides targeting XIAP induce apoptosis and enhance chemotherapeutic activity against human lung cancer cells in vitro and in vivo. Clin Cancer Res 2003; 9: 2826-2836.

37. Shaw TJ, Lacasse EC, Durkin JP, Vanderhyden BC. Downregulation of XIAP expression in ovarian cancer cells induces cell death in vitro and in vivo. Int J Cancer 2008; 122 1430-1434.

38. Yin Q, Lamothe B, Darnay B, Wu H. Structural basis for lack of E2 interaction in the RING of TRAF2. Biochemistry 2009; 48: 10558-10567.
39. Zheng $C$, Kabaleeswaran V, Wang $Y$, Cheng G, Wu H. Crystal structures of the TRAF2: CIAP2 and the TRAF1: TRAF2: CIAP2 complexes: affinity, specificity, and regulation. $\mathrm{Mol}$ Cell 2010; 38: 101-113.

40. Mace PD, Smits C, Vaux DL, Silke J, Day CL. Asymmetric recruitment of clAPs by TRAF2. J Mol Biol 2010; 400: 8-15.

41. Hosokawa Y, Suzuki H, Nakagawa M, Lee TH, Seto M. API2-MALT1 fusion protein induces transcriptional activation of the API2 gene through NF-kappaB binding elements: evidence for a positive feed-back loop pathway resulting in unremitting NF-kappaB activation. Biochem Biophys Res Commun 2005; 334: 51-60.

(c)

This work is licensed under the Creative Commons

Attribution-NonCommercial-No Derivative Works 3.0

Unported License. To view a copy of this license, visit http:// creativecommons.org/licenses/by-nc-nd/3.0

Supplementary Information accompanies the paper on Cell Death and Differentiation website (http://www.nature.com/cdd) 